\title{
Flipped Classroom Model to Enhance Students' Reading Comprehension
}

 \\ ${ }^{1}$ Lampung University, Lampung and Indonesia \\ ${ }^{2}$ Lampung University, Lampung and Indonesia \\ ${ }^{3}$ Lampung University, Lampung and Indonesia \\ *Corresponding author. Email: desydesmitaw@gmail.com
}

\begin{abstract}
Understanding texts means engaging the learners carefully into the text in such a way that they are filtering the information before consuming and discerning it as their understanding. This study aims to examine some different effects of two non-traditional approaches when they are applied in learning reading. Flipped classroom model may provide a wider and more flexible opportunity to students to take stance towards the text. The study inserts the elements of critical thinking standards in learning process of flipped classroom to bring students into a higher level of comprehension. True experimental design is developed. The samples are 65 EFL students on second grades of a senior high school in Pesawaran. The flipped classroom model utilizes the five reading aspects for evaluating the achievement on experimental group and control group. The result reveals that the alternative hypothesis is accepted. There is significant difference of using flipped classroom model integrated with jigsaw IV and original flipped classroom model for students' reading comprehension achievement.
\end{abstract}

Keywords: Reading Comprehension, Critical Thinking Standard, Flipped Classroom Model, Jigsaw IV

\section{INTRODUCTION}

Reading helps students to process and evaluate information in order to build their comprehension. Either natives or EFL learners want to know the meaning when they read a passage [1]. Reading comprehension is the process of simultaneously extracting and constructing meaning through interaction, and involvement with written language [2]. In reading process, interactions between readers and the text or passage bring them to grasp the intended message of the text. Understanding texts means engaging the students carefully into the text in such a way that they are filtering the information before consuming and discerning it as their understanding. Students may spill their beliefs after taking stance towards the text. The complicated process of reading forces the learners to have higher-order thinking skill (HOTS).

Supporting reading with higher level of thinking is needed to encourage active thinking process by teaching students how to evaluate information critically. Actually, at education field in this $21^{\text {st }}$ century era, Indonesia has expected that 2013 curriculum would prepare students to be able to encounter $21^{\text {st }}$ century skills (4C) that is critical thinking and problem solving, creativity and innovation, communication and collaboration. It refers to our educational system in
Indonesia which implemented Bloom's Taxonomy in designing the learning activity from getting knowledge and comprehension on lower cognitive level into application, analysis, evaluation and creation to achieve higher cognitive level. Higher level of thinking or critical thinking skill component refers to the cognitive processes of thinking. Paradigm of critical thinking as "active, purposeful, and organized efforts to make sense of our world by carefully examining our thinking, and the thinking of others, in order to clarify and improve our understanding" [3]. Bassham et.al mention 8 standards to measure someone critical thinking disposition, they are clarity, precision, accuracy, relevance, consistency, logical correctness, completeness and fairness [4].

Flipped classroom model may provide a wider and more flexible opportunity to students to take stance toward the text to achieve higher level of comprehension. Several researchers had proven that flipped classroom model was one of effective teaching model in improving students' reading comprehension on teaching-learning process [5] [6] [7] [8] [9] and in improving students' critical thinking skills [10]. Flip the class activity is a new habit for students and instructors and it does not have precise theoretical framework [11]. Thus, it allows to be adopted in many ways, but the point that this model flip the place and time of exercise 
and explanation, create constructivist learning environment by giving more time for collaboration and engagement for students [11]. Creating active and collaborative environment although giving students opportunity to practice notable skills in learning are significantly important for increase critical thinking skill [12]. Moreover, researches reveal that students have improved higher-order thinking and problem-solving skills through engaged in active learning exercises [13].

Furthermore, referring to the emphasis on the active learning process, Hsieh suggests in order to achieve learning objective, instructors could integrate this model with other interactive learning technique [14]. This active and collaborative learning are created by jigsaw. Jigsaw type IV is one of accepted instructional technique for teaching reading for enhancement of learning interaction and responsibility. Through this modified model, students are allowed to learn before the actual class time, at their extension learning time. They would be more prepared in learning at their own pace, then come to actual class with any information to engage in discussions on the topic and apply their knowledge through active learning. This active learning focuses on comprehension skill and on higher level skills, such as applying, analysing, evaluating and creating.

In learning reading, EFL students oftentimes accept any information they receive from the text without questioning or analysing to draw conclusions based on critical judgments to achieve higher level of comprehension. This can be due to many reasons such as the absence of good instruction, the lack of background knowledge, both teachers and students seem to give less importance to developing more than comprehension skill and the limited time of teachinglearning process, especially practice reading in the classroom. Specifically, in this present study, the EFL students have experienced with traditional procedure such repeating and memorizing techniques and strategies in learning English. Students become passive recipients who accept any information without further thinking and analysis, then teachers have dominant role in learning process. Thus, the need of conducting research in EFL context in which promote studentcentered and active learning process to enhance students' reading comprehension achievement. The research is needed to provide the evidence whether any significant difference of students' reading comprehension achievement between students who are taught through flipped classroom model integrated with jigsaw IV and those who are taught through original flipped classroom model. The critical thinking standard will be adopted to bring learners to a higher level of comprehension.

\section{METHOD}

This research develops true experimental design. To analyze the result of students' reading comprehension test, Independent sample t-test in SPPS version 26 was used in order to compare the students' reading comprehension achievement from experimental group and control group after the treatments. The setting of this research was in Pesawaran. Second grades students at SMAN 1 Gedongtataan as the population of this research. The samples were 65 students: 15 males and 50 females. In experimental group, there were 32 students and in control group there were 33 students. None of the students had any prior experience with the flipped classroom model. As instruments, the researcher used reading comprehension tests for pre-test and posttest. It has been validated and tried-out before administered. The trying out results were used to analyze the items test validity by comparing the value of $\mathrm{r}$ table and $\mathrm{r}$ hitung from Pearson Correlation ProductMoment. Then, cronbach's alpha (0.822) was indicated that it was reliable to use. The test consisted of 40 items with 5 optional which refer to five reading comprehension aspects by Suparman [15].

All students were taught by using flipped classroom model during 3 weeks of treatments. Then, to know the students' ability in reading before treatments, pre-test was given to them. Following to the flipped classroom procedures, before the class time, the students are shared the content of material and the actual class time was used for collaborative learning and active thinking process such a discussion and cooperation with their own classmate. In experimental class, the activities of jigsaw IV merged in flipped classroom phases. In all treatments, students read the text and watched the video explanation for students 2 days before actual class time using online platform such WhatsApp group. However, the discussion sections were different on each treatment. In the first treatment, both of expert and home group discussions were done in actual class time. For second treatment, expert group discussion has been done in outside the classroom and home group discussion was done in actual class time. Then, the third treatment, home group discussion was carried out first in outside the classroom, after that expert group discussion was done in actual class time. They discussed and got clear understanding, then answered all quizzes. After class, students got review from instructor and they must answer evaluation quiz. In control class, instructor followed original flipped classroom phases which adapted to teach reading. 2 days before actual class time, the students read reading text with some questions to guide them to find information which they need. Then, in actual class time, they discussed in pair to answer those guided questions together. They shared their understanding each other based on what they got from reading text. After class, students got review from instructor and answer evaluation quiz. Last, to know students reading comprehension achievement after the treatments, post-test was conducted. In this pandemic condition, the research was conducted through online platform such as WA group, zoom meeting and google form.

Collecting the data from the pre-test and post-test in order to analyze and calculate to know the normality 
and homogeneity of the data, then, took the hypothetical test.

\section{RESULTS AND DISCUSSION}

Testing the normality of the data from experimental group and control group in order to measure whether the data are normally distributed or not is absolute requirement before testing the hypothesis.

In experimental group, there were 32 students and in control group, 33 students as the samples. The ShapiroWilk test must be used in this research since the sample was less than 50, while Kolmogorov-Smirnov test must be used if the sample was more than 50. From the Table 1, it is found that the significant level (Sig.) on ShapiroWilk test are as follow: .104, .076, .118, .422 for all the data of pre-test and post-test from experimental and control group. Since significant level (Sig.) is > 0.05 $(\alpha)$, therefore, $\mathrm{H}_{\mathrm{o}}$ is accepted. The finding is the data have normal distribution.
Testing homogeneity was also conducted to ensure whether the data was homogenous or not. Then, to assess the equality of variances in different sample, it can be seen from the Levene Statistics. The results on Table 2. shows that the significant level (Sig.) is 0.022 based on mean. It means that it is less than $\alpha=0.05$, therefore $\mathrm{H}_{\mathrm{a}}$ is accepted. The finding shows that the variance of students' reading comprehension achievement data from experimental and control group are not homogenous. Since, the homogeneity of data variance is not an absolute requirement, so the independent sample t-test can be still carried out.

Furthermore, the hypothetical test was administered after the data was considered as normal but not homogenous. The hypothetical test was used to prove whether the objective of the research was achieved in this research.

Table 1. Tests of Normality

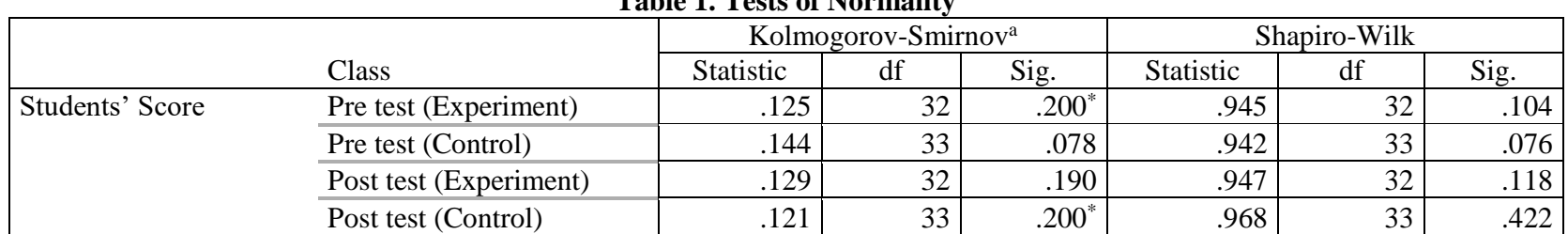

*. This is a lower bound of the true significance.

a. Lilliefors Significance Correction

Table 2. Test of Homogeneity of Variances

\begin{tabular}{|c|c|c|c|c|c|}
\hline & & Levene Statistic & df1 & $\mathrm{df} 2$ & Sig. \\
\hline \multirow{4}{*}{$\begin{array}{l}\text { Students' Score } \\
\text { Achievement }\end{array}$} & Based on Mean & 5.558 & 1 & 63 & .022 \\
\hline & Based on Median & 5.606 & 1 & 63 & .021 \\
\hline & Based on Median and with adjusted df & 5.606 & 1 & 56.434 & .021 \\
\hline & Based on trimmed mean & 5.730 & 1 & 63 & .020 \\
\hline
\end{tabular}

Table 3. Independent Sample Test

\begin{tabular}{|c|c|c|c|c|c|c|c|c|c|c|}
\hline \multicolumn{11}{|c|}{ Independent Samples Test } \\
\hline & & \multicolumn{2}{|c|}{$\begin{array}{l}\text { Levene's Test for } \\
\text { Equality of } \\
\text { Variances }\end{array}$} & \multicolumn{7}{|c|}{ t-test for Equality of Means } \\
\hline & & \multirow[b]{2}{*}{$\mathrm{F}$} & \multirow[b]{2}{*}{ Sig. } & \multirow[b]{2}{*}{$\mathrm{t}$} & \multirow[b]{2}{*}{$\mathrm{df}$} & \multirow{2}{*}{$\begin{array}{l}\text { Sig. (2- } \\
\text { tailed) }\end{array}$} & \multirow{2}{*}{$\begin{array}{l}\text { Mean } \\
\text { Differen } \\
\text { ce }\end{array}$} & \multirow{2}{*}{$\begin{array}{c}\text { Std. } \\
\text { Error } \\
\text { Differen } \\
\text { ce }\end{array}$} & \multicolumn{2}{|c|}{$\begin{array}{l}\text { 95\% Confidence } \\
\text { Interval of the } \\
\text { Difference }\end{array}$} \\
\hline & & & & & & & & & Lower & Upper \\
\hline \multirow[t]{2}{*}{$\begin{array}{l}\text { Students' Score } \\
\text { Achievement }\end{array}$} & $\begin{array}{l}\text { Equal variances } \\
\text { assumed }\end{array}$ & 5.558 & .022 & 4.081 & 63 & .000 & 167.1875 & 40.9706 & 85.3144 & 249.0606 \\
\hline & $\begin{array}{l}\text { Equal variances } \\
\text { not assumed }\end{array}$ & & & 4.106 & $\begin{array}{r}55.32 \\
9\end{array}$ & .000 & 167.1875 & 40.7145 & 85.6047 & 248.7703 \\
\hline
\end{tabular}


By means of the result obtained in table 3. above, the significant (2-tailed) value is .000 , it means that it lower than 0.05 . It can be concluded that there is significant difference between students' achievement in experimental group and control group. Experimental group students got higher mean score than control group students. Students were taught through flipped classroom model integrated with jigsaw IV show better achievement than those who were taught through original flipped classroom model. As the calculation results could be implied that null hypothesis (Ho) is rejected and the alternative hypothesis ( $\mathrm{Ha})$ is accepted.

The aim of this study is to compare the implementation of flipped classroom model integrated with jigsaw IV and original flipped classroom model on teaching reading comprehension for senior secondary students. Considering the fact that EFL students should be provided with more appropriate teaching model in order to reduce the lack of their reading comprehension ability. Therefore, recent innovative teaching model such flipped classroom is suitable to use.

Referring the results of quantitative analysis showed that the flipped classroom modified by integrating with jigsaw IV as an instructional model is considered as more effective since it resulted better achievement in the post-test than pre-test. This finding was in line with other scholars' findings which have found that the flipped classroom model was combined with other cooperative learning techniques resulted better performance on students' learning achievement [16] [17] [18].

Flipped classroom model integrated with jigsaw IV encourages students to become engaged in learning. Modified flipped classroom model changes from teacher-centered to student-centered, from traditional lecture to innovative learning model, and more active pedagogical approach that promote the students to develop higher order skill [19]. The role of students in this model is dominant whereby they are shared the lecture material before class in digital format and they have meaningful time in classroom by doing active and collaborative activities [19]. Since perfectly matches between flipped classroom method together with cooperative learning method in aspect of constructivism and active learning [18]. Therefore, in learning reading through flipped classroom model integrated with jigsaw IV, the students have more prepared to engage in discussions on the topic and to apply their understanding through interaction with their own group.

This modified model also makes the students responsible for their own learning. By asking students to read the text and watch the video then grasp as much information as they get by themselves in outside the classroom 2 days before in-class time. Additionally, in expert group, the students became expert in certain part of reading text, they have to contribute their own understanding in discussion. After that, the home group discussion gave students opportunity to have deeper comprehension on the whole reading text. In other words, the comprehending process have been created since they learn in outside the classroom by building their background knowledges. In inside the classroom, through meaningful and active learning process by discussing with expert or home group, they have to share their understanding each other in order to get more input for their friends in group. Thus, the students have deeper comprehension either on certain part or on the whole text.

Furthermore, some elements in jigsaw IV such 1 work sheet and 3 exercise quizzes were given to explore the students' reading comprehension. The students thought more critically for answer the expert sheet individually to ensure their understanding of the video and reading text. Then, they answered the expert group quiz to check their comprehension and to share information they got from their certain part of text, and answer the home group quiz and evaluation quiz to explore their comprehension towards the whole of text. All these hands-on activities practiced the students' thought to more active to process the information during in actual class time.

Comparing with original flipped classroom model which actually allowing to be adopted in many ways, but the point that this model flip the place and time of exercise and explanation, create constructivist learning environment by giving more time for collaboration and engagement for students [11]. While, in this study, control class students which applied original flipped classroom model were allowed to discuss in pair during actual class time. They discussed the guided questions that have been given to them 2 days before the class time together with the reading text. There was no video explanation related to the topic for control class students and there were only 2 exercises for control class; 1 is guided questions to direct them to grasp any information from the text, and 1 is evaluation quiz to check students' comprehension towards the whole text.

Both of flipped classroom model integrated with jigsaw IV and original flipped classroom model have effectiveness to teach reading, yet the original version did not prove the improvement as high as on modified one. This is because, first, less exercise quiz while they are reading during actual class for students in control class. The teachers' roles of prepare various pre-reading activities and while they are reading is significantly helped students to build predictions and expectations about the text they are going to read [20]. Thus, the role of doing exercise quiz in before or during reading is significant in teaching reading in order to help the students to build comprehension about the text. Second, the students on control class do not shared video explanation related to the topic on reading text. Since giving video explanation to support reading text affect the students' confidence and ability to engage in learning. Supported by Singh et.al that in learning process, giving material through video such as from YouTube as guidance for students, it will build confidence and ability to engage with peers [21]. 
Based on the findings above, there is significant difference of students' reading comprehension achievement between students who are taught through flipped classroom model integrated with jigsaw IV and those who are taught through original flipped classroom model. These differences may be caused related to implementation types. Due to flipped classroom model do not have a strict theoretical framework, it may be adapted in many ways to the implementation which leads to varying results. Instructor has significant role to design the learning materials and activities with consider that actual class time/ activity inside the classroom is crucial for the students to gain more understanding and apply the knowledge through active learning process.

In conclusion, integrating flipped classroom model with jigsaw IV is more effective on students' reading comprehension achievement than original flipped classroom model. Especially teaching reading for EFL students with the large class condition such in this current research, choosing the appropriate technique for allowing students to work collaboratively and engage in actual class time learning to become most important factor to get better result.

\section{CONCLUSION}

Revealed from the result of analysis, implementation of flipped classroom model enhances students' reading comprehension in both of class. Either the flipped classroom model integrated with jigsaw IV or the original flipped classroom model showed increasing score on students' pre-test to post-test. Yet, the better result is showed by students who taught by using flipped classroom model integrated with jigsaw IV. They are engaged in active learning process by discussing, sharing and answering some quizzes together with their own expert and home group. It brought the learner into a higher level of comprehension. Then, the video explanation which given to experimental class students make them easy to visualize information by reading the text with full understanding and watching the video. They relate their thought about what they get from reading text and what it is in the video. Therefore, they more prepare to engage in learning and discussing section.

\section{ACKNOWLEDGMENTS}

Authors are thankful to Lampung University who supported this research by accepting in grant research program.

\section{REFERENCES}

[1] K. Heidari, "Critical thinking and EFL learners' performance on textually-explicit, textuallyimplicit, and script-based reading items," Thinking Skills and Creativity, no. 37, pp. 1-8, 2020.

[2] C. E. Snow, Reading for Understanding: Toward an R\&D Program in Reading, Santa Monica, CA: RAND Corporation, 2002.
[3] S. Kavanoz, "Cultivating Critical Thinking Skills in the EFL Classroom," dalam Preparing Teachers for A Changing World: Contemporary Issues in EFL Education, Trabzon, Vizetek, 2020, pp. 1-166.

[4] G. Bassham, W. Irwin, H. Nardone dan J. M. Wallace, Critical Thinking: A Student's Introduction, 4th penyunt., New York: McGrawHill, 2011.

[5] A. Hashemifardnia, E. Namaziandost dan S. Shafiee, "The Effect of Implementing Flipped Classrooms on Iranian Junior High School," Theory and Practice in Language Study, vol. VIII, no. 6, pp. 665-673, 2018.

[6] Herlindayana, Sahlan dan Albert, "The Effect of Flipped Classroom on Students' Reading Comprehension," Journal of Language Education and Educational Technology, vol. II, no. 1, 2017.

[7] M. Karimi dan R. Hamzavi, "The Effect of Flipped Model of Instruction on EFL Learners' Reading Comprehension: Learners' Attitudes in Focus," Advances in Language and Literary Studies, vol. VIII, no. 1, pp. 95-103, 2017.

[8] E. Kurniawan dan S. Wulandari, "The Effect of Flipped Classroom Toward Students' Achievement in Teaching Reading," Journal of English Teaching Adi Buana, vol. III, no. 1, pp. 1-10, 2018.

[9] R. Fahmi, L. Friatin dan L. Irianti, "The Use of Flipped Classroom Model in Reading Comprehension," Journal of Applied Linguistics and Literacy, vol. IV, no. 1, pp. 77-94, 2020.

[10] E. Voss dan I. Kostka, Flipping Academic English Language Learning: Experiences from an American University, Singapore: Springer Nature Singapore Pte Ltd., 2019.

[11] Z. Turan dan Y. Goktas, "The Flipped Classroom: instructional efficency and impact of achievement and cognitive load levels," Journal of E-Learning and Knowledge Society, vol. XII, no. 4, pp. 51-62, 2016.

[12] M. W. Tolbert, "THE RELATIONSHIP BETWEEN THE FLIPPED CLASSROOM AND CRITICAL THINKING, ACADEMIC PERFORMANCE, STUDENT PERCEPTIONS, AND STUDENT EVALUATIONS IN AN INTRODUCTORY PSYCHOLOGY COURSE," The University of Tennessee at Chattanooga, Chattanooga, 2020.

[13] D. A. Morton dan J. M. Colbert-Getz, "Measuring the Impact of the Flipped Anatomy Classroom: The Importance of Categorizingan Assessment by Bloom's Taxonomy," Anatomical Sciences Education, pp. 1-6, 2016.

[14] B. Hsieh, "Step by Step, Slowly I Flip," dalam The Flipped College Classroom: Conceptualized and Re-conceptualized, Switzerland, Springer International Publishing AG, 2017, pp. i-261.

[15] U. Suparman, Developing Reading Skill and 
Strategies, Bandung: CV Alfino Raya, 2012.

[16] M. Yamada, Y. Goda, K. Hata, H. Matsukawa dan S. Yasunami, "Flip-J: development of the system for flipped jigsaw supported language learning," CALL communities and culture - short papers from EUROCALL , pp. 490-495, 2016.

[17] K. Poluju, C. Rollakanti dan R. Manchiryal, "Using New Technique in Teaching and Learning-Jigsaw Method in Flipped Teaching," dalam Proceedings of ICERI2018 Conference, 2019.

[18] D. Erbil, "A Review of Flipped Classroom and Cooperative Learning Method Within the Context of Vygotsky Theory," Frontiers in Psychology, vol. XI, pp. 1-9, 2020.

[19] M. Hartyanyi dan et al, Innovating Vocational Education: Flipped Classroom in Practice, Cork: Eramus, 2018.

[20] E. Martiarini, "The Effect of Speed-Reading Method Upon Students' Reading Comprehension," DEIKSIS, vol. V, no. 2, pp. 89-105, 2013.

[21] H. Singh dan et al., "A Review of Research on Flipped Classroom Approach for Teaching Communication Skill in English," International Journal of Academic Research in Business and Social Sciences, vol. VII, no. 10, pp. 100-118, 2017. 